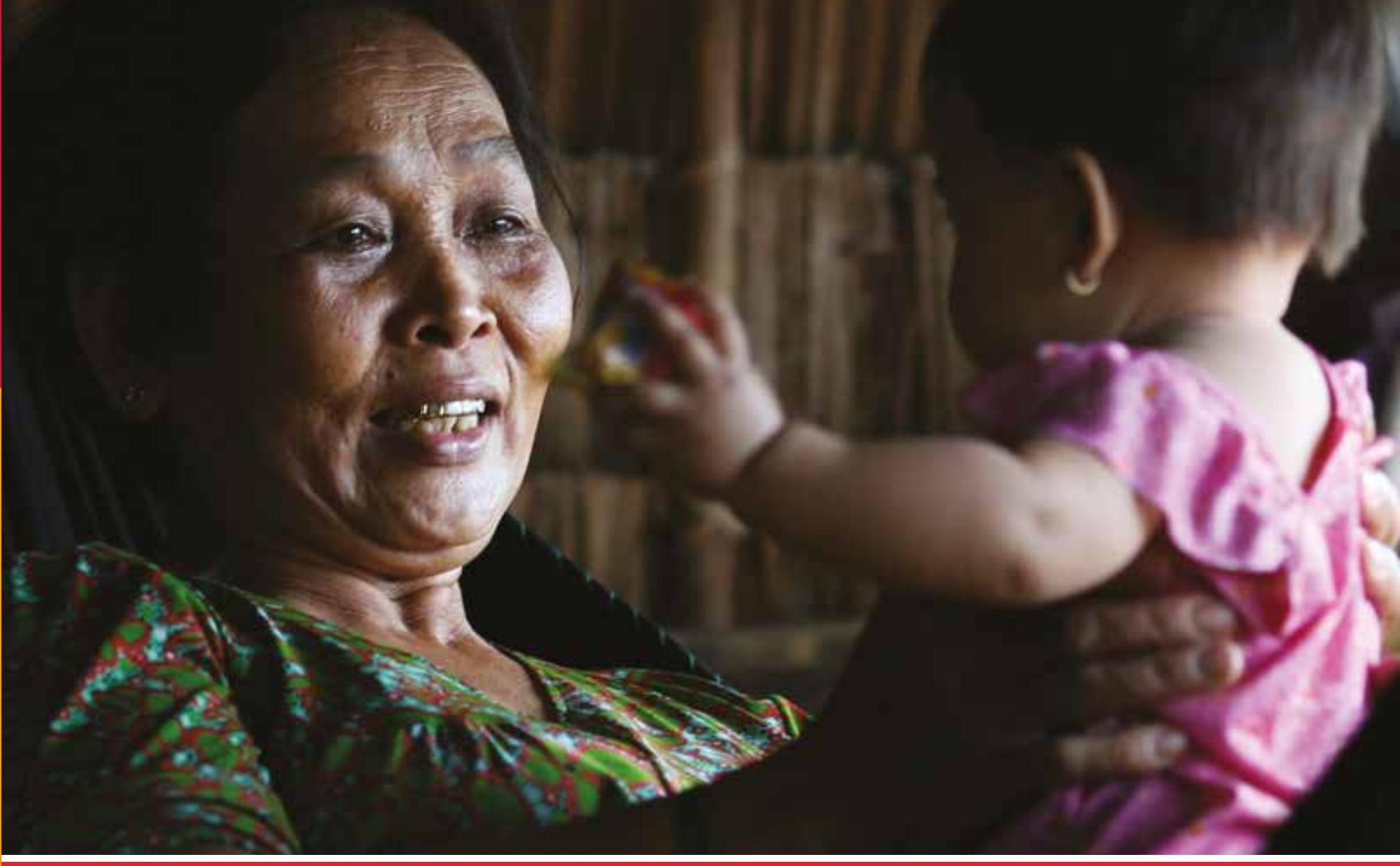

\title{
PARTICIPATORY METHODOLOGY: RAPID CARE ANALYSIS
}

Guidance for Managers and Facilitators

Thalia Kidder and Carine Pionetti, July 2013

Revised by: Unity Chipfupa, Jane Remme and Thalia Kidder, October 2016 


\section{Table of contents}

1 Introduction 3

2 Why a Rapid Care Analysis? $\quad 4$

2.1 What is 'Rapid Care Analysis'?

2.2 Why conduct a Rapid Care Analysis?

2.3 Why focus on care? $\quad 5$

2.4 How will Rapid Care Analysis fit within our existing work?

2.5 Change strategy - how does change happen in care? $\quad 6$

$\begin{array}{ll}2.6 \text { Key concepts in 'care' } & 7\end{array}$

3 Setting the parameters for using Rapid Care Analysis 9

3.1 Scope the planned RCA $\quad 9$

3.2 Choose the RCA facilitation team 9

3.3 Orientation of facilitation team 9

$\begin{array}{ll}3.4 \text { Brief the gatekeepers } & 10\end{array}$

3.5 Consider your advocacy strategy 10

4 Planning and running the Rapid Care Analysis $\quad 12$

4.1 Making decisions about how to use the RCA tool 12

4.2 Rapid Care Analysis checklist for planning $\quad 14$

4.2.1 Planning: four to eight weeks before the RCA 14

4.2.2 Planning: one to two weeks before the RCA $\quad 15$

4.2.3 Final planning - two to three days before the RCA 16

$\begin{array}{ll}\text { 4.2.4 On the day(s) of the RCA } & 17\end{array}$

$\begin{array}{ll}\text { 4.2.5 After the RCA } & 18\end{array}$

4.3 Guidance for documenters - ensuring good quality documentation and reporting 18

5 Getting support and giving feedback $\quad 19$ 


\section{INTRODUCTION}

This Guidance Document provides support for programme managers and others seeking to integrate care analysis into their work, and to better understand how care is provided and its implications for carers, women, men, girls, and boys. It explains why care analysis is important; provides definitions of key concepts relating to care; and offers tips and guidance for anyone seeking to use the accompanying Rapid Care Analysis Toolbox. The Toolbox offers exercises both for programme managers who want simple, straightforward questions and rapid outputs, and for those who intend to engage in a longer process of awareness-raising and change regarding care provision.

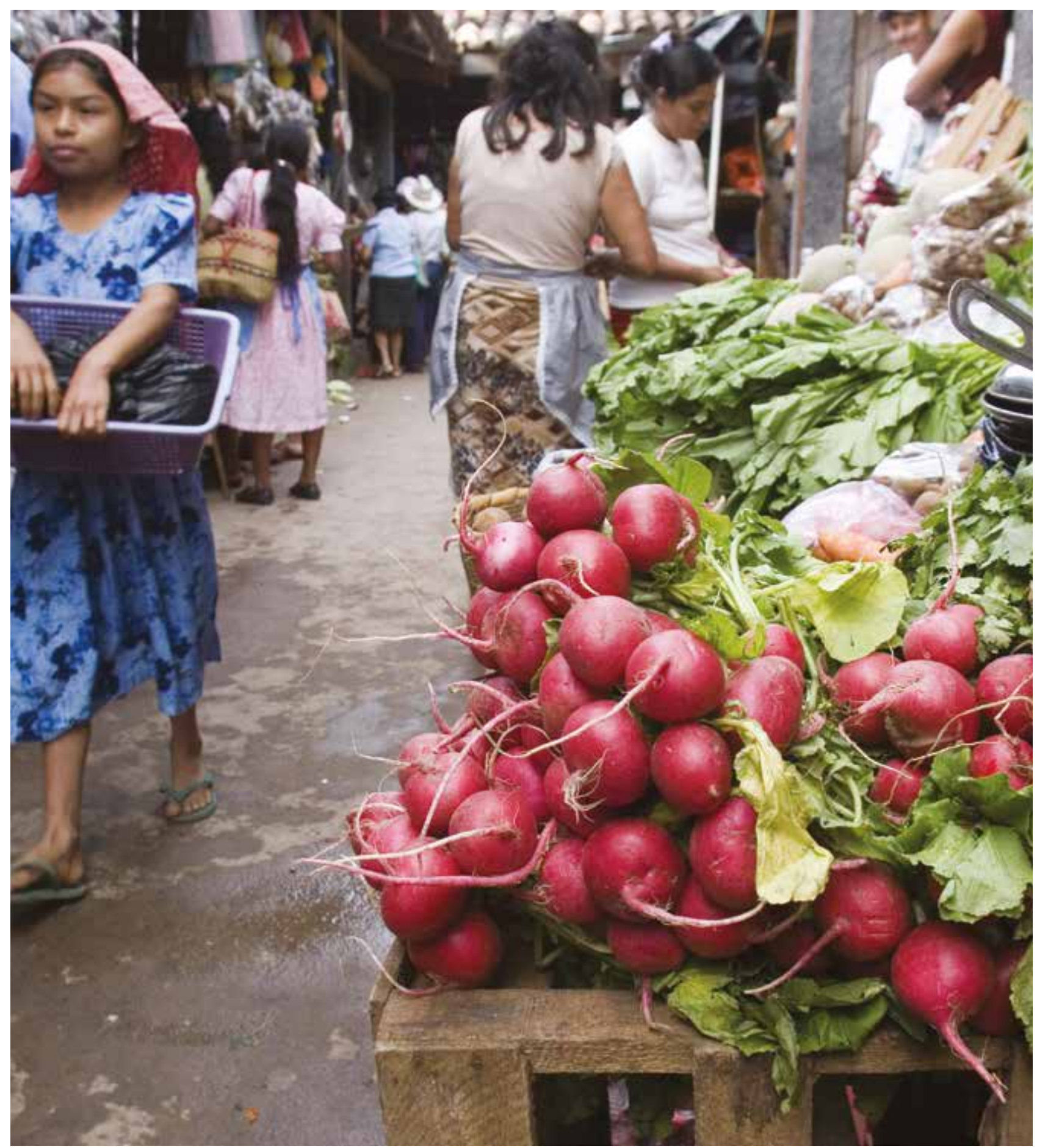




\section{WHY A RAPID CARE ANALYSIS?}

\subsection{What is 'Rapid Care Analysis'?}

Rapid Care Analysis (RCA) is a set of exercises for the rapid participatory assessment of unpaid household work and care for people in communities. It has been used by Oxfam, local groups, and humanitarian and development agencies to improve the design and outcomes of their programmes. Assessments of care show how women's responsibility for care work may impact on their participation in or benefit from development projects. Assessments also seek to make visible and improve understanding of patterns of unpaid care work in communities, and to enable the identification of problems and their solutions. The RCA is intended to be simple, low-cost, quick to use, and easy to integrate into existing exercises for programme design or monitoring. ${ }^{1}$ The tool comprises eight exercises aimed at achieving four specific purposes, ${ }^{2}$ which are to:

i) Explore relationships of care in the community.

ii) Identify unpaid and paid work activities performed by women and men, and create a rough estimate of average weekly time spent on each category of work by men and women.

iii) Document care for women, men, girls, and boys at a household level, changes in care tasks due to external factors Imigration, policies, disasters, etc.J, explore social norms impacting on care work, and identify the most problematic care activities for women and the community.

iv) Map care support services and infrastructure, identify and prioritise options for reducing and/or redistributing care work.

\subsection{Why conduct a Rapid Care Analysis?}

The RCA exercises are effective in helping inspire local groups to understand care work in their area and find practical solutions to problematic tasks and patterns of care.

The RCA can be critical for uncovering less-understood issues that women and girls face to participation in humanitarian and development programmes, and to benefit equitably from such programmes. Equally, by showing the patterns of care that exist in a specific context, the tool can help ensure that groups of vulnerable or dependent people will continue to receive adequate care during situations of crisis or stress. The RCA can be used in designing or adjusting programmes, through gathering evidence to identify practical interventions that can reduce the time or labour required for daily housework and caring for people. For example, a month or two after the earthquake in Nepal (2015) and typhoon in the Philippines (2013), RCA findings were used to improve the design of immediate interventions lemergency food and livelihoods) and of longer-term responses (water, sanitation and hygiene programme; advocacy) to mitigate the effects of the disasters. For example, participants identified the need for communal kitchens, laundry facilities and equipment for childcare. RCA exercises in Oromia, Ethiopia identified collecting firewood as the most problematic care task, leading to the designing of a fuel-efficient stove lusing less firewood and eliminating indoor smoke).

\section{BOX 1: WHAT RCA IS NOT}

- RCA is NOT a standalone tool for awareness-raising; it is a diagnostic tool. Thus, it shouldn't be repeated many times as an awareness-raising session. Other exercises are designed for learning about care or shifting social norms around care roles (see footnote 1).

- RCA is NOT a rigorous quantitative methodology but offers a snapshot of the situation regarding unpaid care work in a community. For rigorous evidence on unpaid care work, please consider using the RCA in conjunction with the Household Care Survey approach. 
While not designed as an awareness-raising session, the RCA methodology does transform participants' understanding of the value and significance of unpaid care work. The RCA can be used to begin or support longer processes of awareness-raising and change on how care is provided in communities. The RCA

exercises are designed to lead to proposals about how the responsibility for providing care can be

redistributed from women to men, and how the costs of care services can be shifted from poor families to the state.

Please note: A good practice recommendation is that organisations using the RCA commit the resources to engage in follow-up activities, or at least provide adequate support for communities who want to use the findings in their own advocacy efforts.

\subsection{Why focus on care?}

The vision: New patterns of providing care are a means of addressing inequality and of promoting women's

empowerment. Quality care is critical for human well-being. Investing in care has a widespread, long-term, positive impact on well-being and economic development. Although care is a 'public good', it remains almost universally women's responsibility. Heavy and unequal responsibility for unpaid care work, without adequate support, is linked to poverty and social exclusion. Oxfam aims to increase the recognition of care work, reduce the drudgery of care work, redistribute responsibility for care more equitably, and ensure the representation of carers in decision making, as a precondition for achieving women's political, social, and economic empowerment.
How practical is the RCA tool? Care analysis and interventions on care are possible and doable. Oxfam's experience of using RCA in different regions lover 20 countries), since 2013 when the tool was developed, shows that a rapid analysis of care gives enough information to start something, to identify and prioritise feasible interventions. It is true that changing the ways in which care is provided may take decades. However, a few practical interventions focusing on care have been inspiring and motivating to communities and programmes. Practical steps can help ensure that women can participate and benefit more from various development programmes and can have their work more recognised and valued, and have often resulted in changes in gendered norms and behaviours around unpaid care work.

For example, in Honduras, advocacy informed by RCA findings resulted in the government accelerating the installation of a US\$100,000 electricity-generating project used to power water pumps, grain-grinding mills and refrigeration. In Zimbabwe, findings from the RCA supported awareness-raising with men and women through the 'WE-Care Champions', and a local company offered support for the installation of water tanks in Bubi district. In Uganda, the programme team used RCA findings in meetings with the Ugandan Bureau of Statistics, advocating that time-use and care indicators be included in the Demographic and Health Survey. In Bangladesh, the RCA was used in an urban setting with domestic workers, findings of which informed lobbying with employers for equipment that reduces time spent on the most problematic tasks in their homes. 


\subsection{How will Rapid Care Analysis fit within our existing work?}

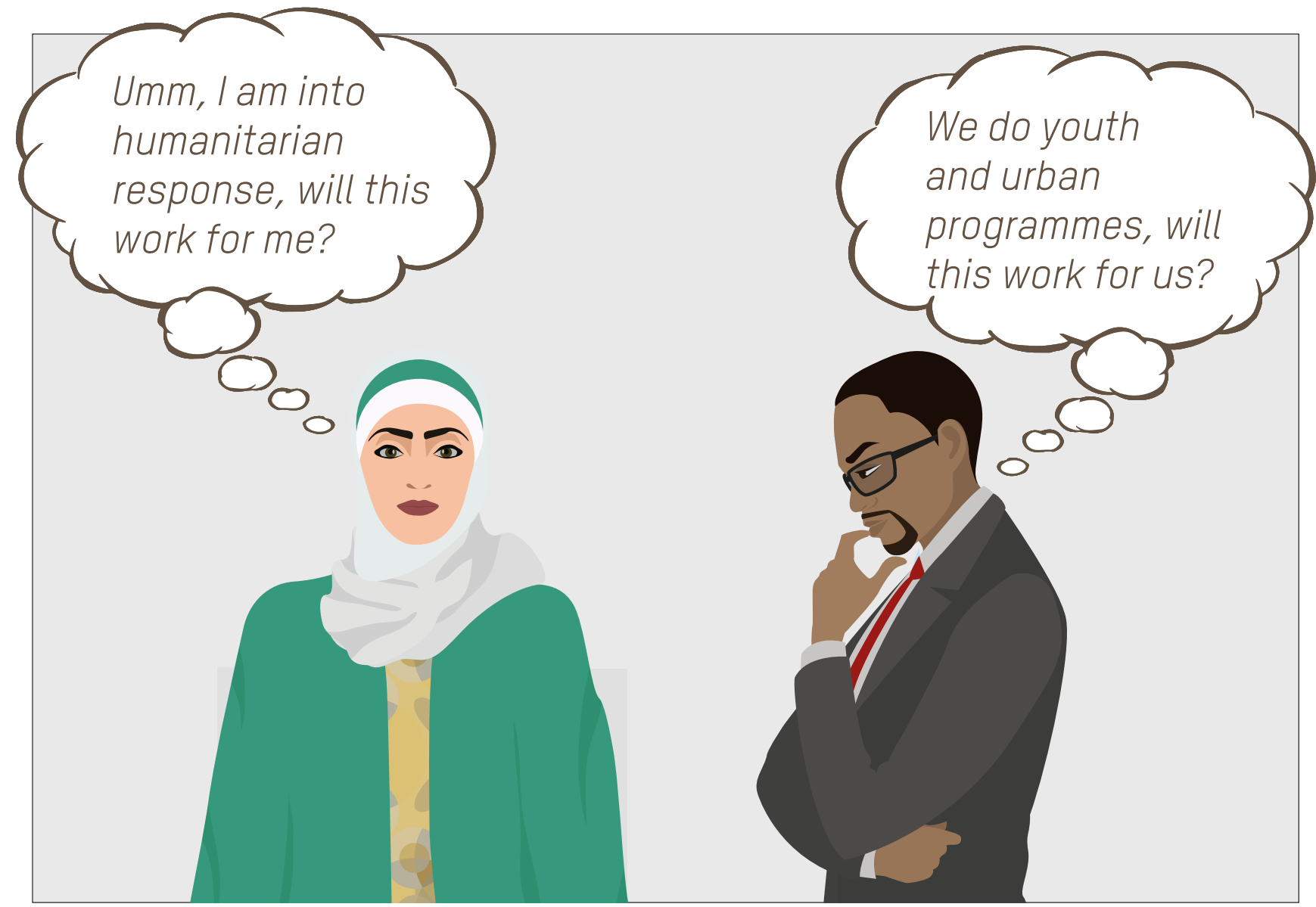

\section{Yes!!! Oxfam's experience shows that care analysis is relevant for any programme.}

The RCA exercises have been used in programmes such as post-disaster response and recovery, youth, urban development, rural development, enterprise and markets, women's leadership, health and HIV services, livelihood recovery and policy advocacy, among others. The outputs of an RCA include:

- An estimate of the hours women and men spend on work activities, including care.

- Community map of the work, infrastructure, and services currently required to care for people.

- Changes in care patterns due to crisis, disaster, policy changes, migration or other factors

- Three or four 'main problems' with current care work, e.g., laborious time-intensive tasks, mobility restrictions, or health impacts.

- An understanding of the underlying social norms that underpin perceptions of care and expectations of women and men.
- Prioritised proposed solutions to address these problems.

Findings from RCA exercises have often improved the effectiveness of programme design and efficiency in achieving programme outcomes. They can also be used as a tool for community-led and civil society-led advocacy. The RCA discussions also result in community groups and leaders taking on the issue of unpaid care, owning the findings, and using them for their own plans and advocacy.

\subsection{Change strategy - how does change happen in care?}

'We can make care work visible, show how it's

significant, make it everyone's issue, and address it with simple steps.' Programme officer involved in RCA exercises

- Be practical. 'Care' is not a new issue. For years, emergency and development programmes across the 
globe have considered care work - implicitly or explicitly - for example, planning activities 'around' 'domestic work' or 'women's family responsibilities'. But many people are uncertain about how change could happen in terms of who does care work, or how it's provided. How can a group shift household practices that are private, cultural, complicated, sensitive, and deep-rooted? Rather than addressing the issues all at once, the RCA exercises offer practical solutions to start to facilitate change.

- Build wide support and be positive. The RCA exercises define 'care for people' as a concern of the whole community rather than situating care as a 'women's issue'. The purpose of this is to build ownership of and commitment to the process. The RCA does not consider care as a burden but a societal good, and understands that care benefits the whole society.

- Small steps are a good start. 'Quick wins' from practical improvements in care work build confidence, inspiration and commitment to keep going. They also show that change is possible and advantageous, and create buy-in on the issue, enabling more significant shifts in perceptions and attitudes towards the work women do and care work in general.

- A transformational agenda. In the medium- and long-term, a more ambitious agenda and change strategy will include: recognition of the value of care; investments to facilitate care work; changes in beliefs; reduction and redistribution of responsibility and costs of care; revaluing women's work; and importantly, the representation of carers in decision making at household and community/government levels. Unequal responsibility for care work is a fundamental barrier to women's rights and poverty reduction.

\subsection{Key concepts in 'care'}

In this section, we briefly discuss some of the most common concepts and terminology used in discussions about care. ${ }^{3}$

- Unpaid care work lalso called household work, domestic labour, family work, or reproductive work): Unpaid care work refers to the provision of services for family and community members outside of the market, where concern for the well-being of the care recipients is likely to affect the quality of the service provided (Folbre, 2006; Esquivel, 2013).

- Simultaneous activities: Caring for persons is often performed at the same time as other activities. For example, someone might be supervising cooking while gardening, or supervising children, washing clothes, and attending customers in a family shop. When we analyse care, it is important to record simultaneous activities accurately, because otherwise we can underestimate the amount of unpaid care work that is being done. 'Engaging in simultaneous activities lusing time more intensively by doing two or more things at the same timel provides households with more unpaid work at the cost of higher work intensity for those who provide it' (Floro, 1995).

- Supervision responsibilities: 'Supervision' refers to the responsibility to 'look after' dependants for a period of time. Supervision may require only a few minutes of 'work' in any hour, or no activity or work at all, for example when a baby is sleeping. However, responsibility for supervision limits the carer's choice of primary activity, restricts her/his mobility, and can increase her/his isolation. It also creates uncertainty about plans and schedules, and can lower productivity in work activities. The dependants can either be children or dependent adults who are unable to fully care for themselves le.g. because they are disabled or ill). It is important to recognise supervision responsibilities in addition to simultaneous activities. Monitoring and measuring 'supervision' shows the intensity of care responsibilities, limitations to mobility/choice of activity/productivity, and points to the need for childcare or dependent-adult care services, for example. In rural communities where Oxfam has carried out Household Care Surveys, women have commonly reported that, including responsibility for supervision, they have 10-14 hours per day with responsibility for care (Rost et al., 2015).

- Care and lifecycles: Women's and men's care responsibilities and care work change significantly during their lifecycles - when they are children, when studying, when forming families and raising children, later in life, and in old age. International time-use studies show that the gender gap in unpaid care work may be quite small for certain age groups in certain cultures Isay only 0.5 hours per day more for 20 -yearold women than for 20-year-old men). However, the gender gap usually becomes wider during the years of caring for small children. The cumulative gender differences in unpaid care work responsibilities over the lifecycle lead to significant gender inequality in outcomes in poverty, employment, and political participation. 
- Redistributive agenda: The Four ' $R$ ' framework ${ }^{4}$ proposes that equitable care provision can be promoted, as previously explained. It is a framework for analysing avenues for change towards more just ways of distributing the costs and benefits of unpaid care work. Recognition of unpaid care work is important, but recognition does not necessarily lead to demands for the reduction or redistribution of women's work between women and men, or between families and communities and the state (Esquivel 2013). ${ }^{5}$ The representation of carers in decisionmaking platforms is critical so that positive changes are sustainable over time.

- Care versus leisure: In many contexts, some types of care work are misunderstood as 'leisure', such as caring for children, cooking, or supporting dependent adults. Likewise, a distinction should be made between 'cooking for a wedding or religious event' which is housework/care work - and attending the event, which is probably 'leisure'. Similarly, moral support and listening are mostly 'one-way' care activities, while socialising, which is 'two-way', is closer to recreation and entertainment.

- Distinguishing between care work and food production: Producing food or other products le.g. working in the fields or gardens) is classified as 'unpaid farm work' but not as 'unpaid care work'. What is considered as 'care' is the preparation of food, i.e. processing and cooking, which are services rather than products. The RCA clarifies these distinctions.

- Context-specific definitions of unpaid care work: In focus group discussions around the world, debates about the scope of 'care activities' show that in each context the definitions of unpaid care work differ. In some contexts, praying for someone is considered a 'care activity', or care of household pets and even marital sex. RCA recognises the existence of such differences, and facilitators have some flexibility to adapt the definition of 'care activities' to local contexts. However, the global definition of unpaid care work is retained to maintain the comparability of the RCA findings across different populations, communities and countries. It is still important to document these context-specific understandings of care, even if it is decided not to count them as care work in the RCA (please see Annex 1 for an example of how the RCA was adapted to a specific context, in this example it was the RCA guidance document for RCAs in the Acholi region of Uganda).

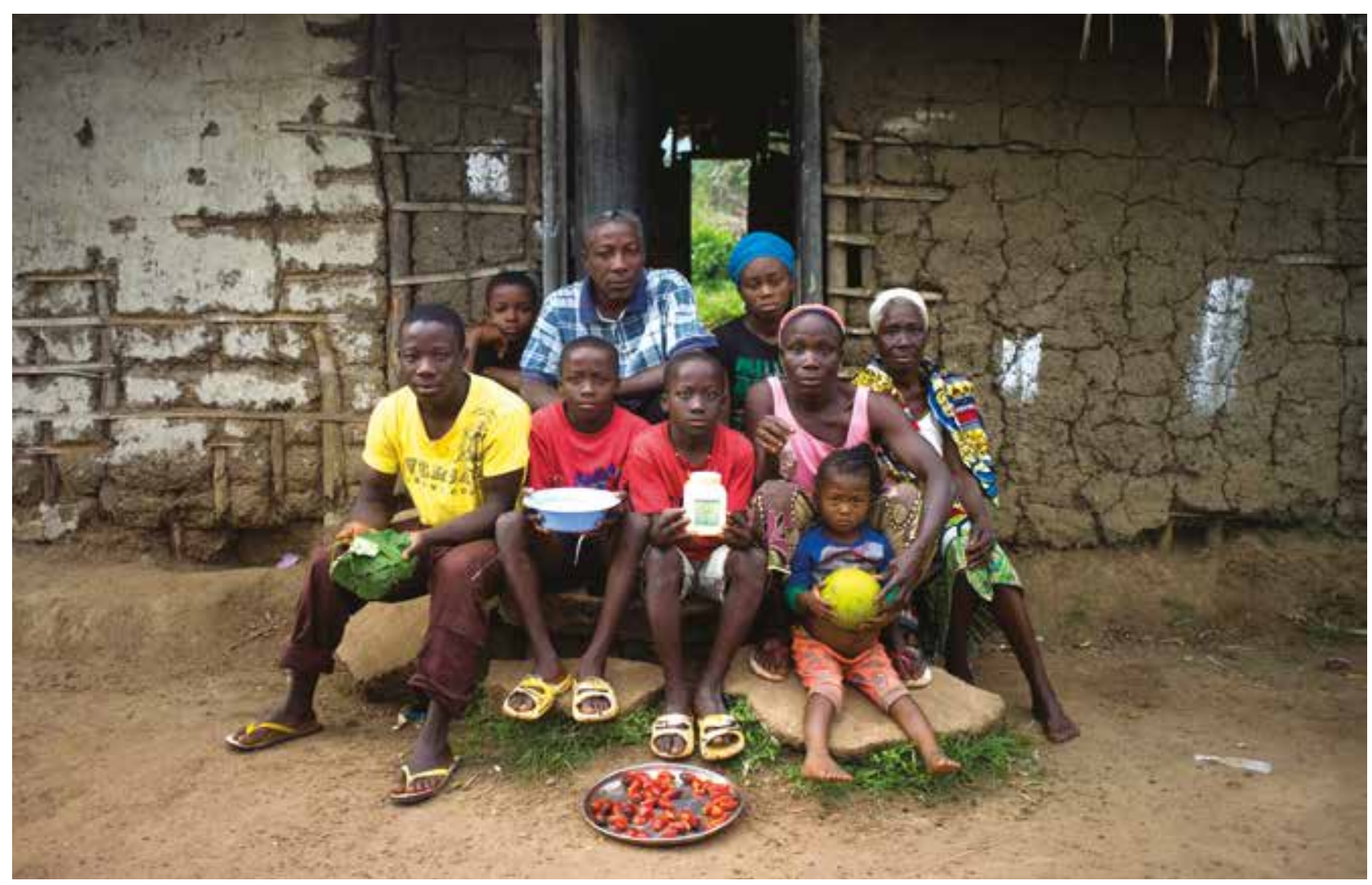




\section{SETTING THE PARAMETERS FOR USING RAPID CARE ANALYSIS}

This section aims to help managers, coordinators and facilitators to lay the groundwork for an effective RCA through fully scoping, planning and preparing for the event.

\subsection{Scope the planned RCA}

Define the purpose and scope of the RCA. Discuss and set up clear expectations in relation to resources, timeline, staff time, the involvement of beneficiaries, locations, and follow-up plans. Consider the following questions:

-What is it your objective in conducting the RCA?

-What do you expect the results to be?

- Is the exercise aimed at a single project or community, or is it for a whole programme or province?

- For any proposals that result from the care analysis are there funds available from the 'host programme' and/ or is there a commitment to support fundraising?

- Who are you working with on the ground?

-Who will provide follow-up?

-Who can use the RCA findings, and how, for advocacy?

If the exercise is for a whole programme or province, it may be that more than one RCA is needed, with assessments spread across the programme area, including individual communities. For example, if the province has both rural and urban communities, conducting the RCA in both settings would enable findings to be as representative as possible.

Please note that when using the RCA to inform postdisaster responses, timelines for planning for the RCAs are greatly reduced. Thus, in countries or communities that are prone to disasters and predictable shocks, time and resources should be invested to better understand care patterns before the disaster or crisis happens, i.e. the RCA should form part of disaster risk reduction activities. Previous experience of how care patterns were affected by shocks should be used to inform first phase emergency responses.

\subsection{Choose the RCA facilitation team}

RCA exercises generate better results when conducted with a team of four to five people. The team includes two facilitators (female and male), a documenter, and an assistant.
Who facilitates? Facilitators can be staff from local organisations, or consultants, who have the following skills:

- Experience working on gender issues ${ }^{6}$ and an understanding of care work.

- Knowledge of participatory methodologies, with experience in facilitating focus groups that include people of different economic/social status.

- Experience and knowledge of the local area or region.

- Fluency in the relevant local languages.

If the RCA is targeting children (younger than 18 years) among the participants, the following additional skills will be a prerequisite:

- Experience working with children or adolescents.

- Strong understanding of child protection and safeguarding issues.

- Awareness of and adherence to relevant child protection and safeguarding policies le.g. if conducted by Oxfam or Oxfam partner organisation, it is imperative to follow the organisation's child protection and safeguarding policies).

It is also desirable to have a documenter (more below) and an observer (or two), especially for the first RCAs done by a team new to the approach. This is preferably someone with some knowledge on care analysis and gender, who will be able to assist the facilitation team in implementing the RCA exercises and explaining tasks and concepts.

See also RCA checklist (section 4.2.1).

\subsection{Orientation of facilitation team}

Once the facilitation team has been put in place, it is important to set aside time to brief and train the team on the RCA methodology. You may choose to run through each exercise, and perform each exercise to improve your understanding of the process, time required, and possible challenges. This will take the form of a one- or two-day orientation workshop, and should also enable in-depth planning of the RCA exercises. Learning from previous experience with the RCA suggests that you might wish to consider the following key points with the team at this stage: 
- Depending on the purpose of the RCA, the type of participants and the experience of facilitators, the orientation workshop could include a session on gender equality or children's issues.

- Practising the RCA exercises allows facilitators to gain practical experience of conducting the RCA and to think about how they might cope with particular scenarios, e.g. if a majority of participants are illiterate, uncomfortable questions etc.

- At the end of the workshop, discuss the logistics of mobilising participants and local authorities, and consider ethical considerations regarding the community.

- Others have used the orientation of the facilitation team to start adapting and contextualizing the RCA Toolkit to the target audience and community.

- If advocacy is a key output of the RCA, developing a power analysis during the orientation of the facilitation team would benefit the approach to facilitation and prioritising the most important questions that need to be addressed.

See also RCA checklist (section 4.2.2 and 4.2.3).

\subsection{Brief the gatekeepers}

'Gatekeepers' are influential people in the target communities or institution where the RCA is being conducted. They are the guardians of the values and culture in a community or an organisation and include among others traditional or religious leadership, local government, and sometimes employers. Oxfam's experience is that briefing gatekeepers on care work and its value to the society increases the acceptance of discussing 'care' and makes future advocacy easier. Who you target with this orientation will depend on the scope and purpose of the RCA. In some cases, some programmes have decided to run separate RCAs composed of men and women leaders only, in preference to having 'powerful' leaders alongside community members in the same group. This is recommended for programmes focusing on advocacy and policy.

See also RCA checklist (section 4.2.2).

\subsection{Consider your advocacy strategy}

Developing your advocacy strategy before conducting the RCA will allow you and your team to match the outputs of the RCA to the evidence required to influence the different stakeholders /see Annex 5 of the Toolbox for Action points for Advocacyl. This can be achieved through a power analysis exercise during the 'orientation of the facilitation team' workshop. See Figure 1 below on how to go about this exercise and the questions you should ask. Facilitators can then shape and direct the RCA exercises to ensure that the participants discuss issues relevant to advocacy, and that discussions generate the most useful evidence and indicators. For example, following the power analysis, facilitators may choose to focus more on public services than on families' division of care tasks between girls and boys.

The power analysis is a starting point to support the development of your advocacy strategy; you will finalise this immediately after the RCA. As an example of what your advocacy strategy could involve, for local-level advocacy you could look at the district development plan (or equivalent) and organise meetings with traditional leadership and elected representatives of the community (either municipal or parliamentary). At national level you could start by seeking an audience with a ministry with which your group has contacts. Once you have an understanding with this ministry, together you could organise a meeting and invite all the key stakeholders at national level that your power analysis identified. At such meetings, present a policy brief highlighting key messages from your RCA findings that are likely to appeal to your stakeholders. Follow up such meetings with individual engagements to affirm some action points raised in the meetings. Together with the ministry and other stakeholders who have shown interest, you could decide to approach the parliamentary portfolio committees responsible for the different sectors relevant to the discussions and participants' proposed solutions, e.g. energy, health and finance, among others. Remember that at national level the power is in the number of key stakeholders you manage to convince of your message. The chances of success in national influencing are enhanced where alliances and coalitions exist between different stakeholders. For more information on national-level influencing, also see Oxfam's National Influencing



Please note, as indicated earlier, the RCA is not a quantitative rigorous methodology. However, a few RCAs in an area could be considered representative of the patterns of care work in similar communities, presenting 'good enough' evidence to start discussions and advocacy activities with policy makers, even at the national level. 
Figure 1: Power analysis - matching the evidence to the target audience ${ }^{8}$

\begin{tabular}{|c|c|c|c|c|c|c|}
\hline $\begin{array}{l}\text { What is the } \\
\text { objective of } \\
\text { the } \\
\text { advocacy? }\end{array}$ & $\begin{array}{l}\text { At what level } \\
\text { is the } \\
\text { advocacy } \\
\text { targeted? }\end{array}$ & $\begin{array}{l}\text { Who are the } \\
\text { key } \\
\text { institutions } \\
\text { or persons to } \\
\text { influence? }\end{array}$ & $\begin{array}{l}\text { What is the } \\
\text { interest of } \\
\text { each } \\
\text { stakeholder } \\
\text { in the subject } \\
\text { matter? }\end{array}$ & $\begin{array}{l}\text { What kind of } \\
\text { evidence is } \\
\text { appealing to } \\
\text { each } \\
\text { stakeholder? }\end{array}$ & $\begin{array}{l}\text { What is the } \\
\text { rigour of } \\
\text { evidence } \\
\text { required? }\end{array}$ & $\begin{array}{l}\text { What spaces } \\
\text { or platforms } \\
\text { could be used } \\
\text { to influence? }\end{array}$ \\
\hline $\begin{array}{l}\text { This is what } \\
\text { you intend to } \\
\text { achieve with } \\
\text { your } \\
\text { advocacy } \\
\text { activities. } \\
\text { For example: } \\
\text { - Create } \\
\text { awareness of } \\
\text { the } \\
\text { importance } \\
\text { of care. } \\
\text { - Promote } \\
\text { investment in } \\
\text { childcare and } \\
\text { health } \\
\text { facilities. }\end{array}$ & $\begin{array}{l}\text { These are } \\
\text { your different } \\
\text { levels of } \\
\text { influence: } \\
\text { - Household } \\
\text { - Community } \\
\text { - Local } \\
\text { - National } \\
\text { Select } \\
\text { appropriate } \\
\text { level/s given } \\
\text { your } \\
\text { objective. }\end{array}$ & $\begin{array}{l}\text { - Household } \\
\text { members } \\
\text { - Religious, } \\
\text { political and } \\
\text { traditional } \\
\text { leadership } \\
\text { - Local } \\
\text { government } \\
\text { - NGOs } \\
\text { - Government } \\
\text { - Donors } \\
\text { - Taskforces } \\
\text { - Portfolio } \\
\text { committees } \\
\text { - Private sector } \\
\text { You may want } \\
\text { to name } \\
\text { individuals if } \\
\text { you know } \\
\text { them and } \\
\text { their level of } \\
\text { influence. }\end{array}$ & $\begin{array}{l}\text { - Strongly } \\
\text { oppose } \\
\text { - Oppose } \\
\text { - Neutral } \\
\text { - Support } \\
\text { - Strongly } \\
\text { support } \\
\text { Be careful } \\
\text { with your } \\
\text { message, } \\
\text { approach, } \\
\text { and language } \\
\text { with those } \\
\text { who oppose. } \\
\text { Turn those } \\
\text { who support } \\
\text { into your } \\
\text { partners, and } \\
\text { find the role } \\
\text { they can play. }\end{array}$ & $\begin{array}{l}\text { - Qualitative } \\
\text { data or } \\
\text { stories } \\
\text { - Quantitative/ } \\
\text { numerical } \\
\text { data } \\
\text { Tailor your } \\
\text { messages to } \\
\text { suit the } \\
\text { target } \\
\text { audience or } \\
\text { stakeholder. } \\
\text { For example, } \\
\text { evidence on } \\
\text { gender } \\
\text { relations } \\
\text { might be ok } \\
\text { for } \\
\text { stakeholders } \\
\text { working with } \\
\text { women, but } \\
\text { ministries of } \\
\text { health might } \\
\text { be more } \\
\text { interested in } \\
\text { knowing } \\
\text { distances } \\
\text { that women } \\
\text { travel to } \\
\text { access a } \\
\text { health } \\
\text { facility. }\end{array}$ & $\begin{array}{l}\text { Rigorous } \\
\text { Less rigorous } \\
\text { Depending on } \\
\text { the } \\
\text { stakeholder, } \\
\text { the demanded } \\
\text { rigour of } \\
\text { evidence } \\
\text { varies. Some } \\
\text { are more } \\
\text { interested in } \\
\text { rigorous, } \\
\text { statistically } \\
\text { representative } \\
\text { data, whilst } \\
\text { for others } \\
\text { rough } \\
\text { estimates, e.g. } \\
\text { of time use, } \\
\text { will suffice. } \\
\text { For others, } \\
\text { qualitative } \\
\text { stories are } \\
\text { enough. }\end{array}$ & $\begin{array}{l}\text { - Door to door } \\
\text { - Residents' or } \\
\text { community } \\
\text { meetings } \\
\text { - One-on-one } \\
\text { meetings } \\
\text { - Monthly } \\
\text { stakeholder } \\
\text { meetings } \\
\text { - Stakeholder } \\
\text { workshops } \\
\text { - Roundtable } \\
\text { discussions } \\
\text { Remember it } \\
\text { might be } \\
\text { desirable to } \\
\text { meet some } \\
\text { key } \\
\text { stakeholders } \\
\text { individually } \\
\text { before } \\
\text { engaging } \\
\text { them in a } \\
\text { wider forum. } \\
\text { Note: your } \\
\text { choices have } \\
\text { financial } \\
\text { implications, } \\
\text { and need } \\
\text { proper } \\
\text { planning. }\end{array}$ \\
\hline
\end{tabular}




\section{PLANNING AND RUNNING THE RAPID CARE ANALYSIS}

\subsection{Making decisions about how to use the RCA tool}

After reviewing the Toolbox of Exercises, facilitators and programme managers/leaders can make strategic decisions about which workshop exercises to select, based on your agreed objectives for the RCA. This section can be used to facilitate this decision-making process.

Table 1: RCA exercises for achieving each purpose and its objectives

\begin{tabular}{|c|c|c|}
\hline Purpose & Exercises & Objective \\
\hline $\begin{array}{l}\text { Explore relationships of care } \\
\text { in the community }\end{array}$ & $\begin{array}{l}\text { Exercise 1: } \\
\text { Care roles and relationships }\end{array}$ & $\begin{array}{l}\text { Get participants to reflect on who they care for and who } \\
\text { cares for them, and how relationships of care build on } \\
\text { social roles in the family and community }\end{array}$ \\
\hline $\begin{array}{l}\text { Identify women's and men's } \\
\text { work activities and estimate } \\
\text { average hours per week }\end{array}$ & $\begin{array}{l}\text { Exercise 2: } \\
\text { Time use }\end{array}$ & $\begin{array}{l}\text { Make visible the total volume of work done by women and } \\
\text { men in a given context/community, and identify the share } \\
\text { of care work done by women and men }\end{array}$ \\
\hline \multirow{4}{*}{$\begin{array}{l}\text { Identify gendered patterns in } \\
\text { care work, social norms } \\
\text { influencing care work } \\
\text { patterns, changes in care } \\
\text { patterns, and most } \\
\text { problematic care activities }\end{array}$} & $\begin{array}{l}\text { Exercise 3: } \\
\text { Distribution of care roles }\end{array}$ & Explore the distribution of care roles at household level \\
\hline & $\begin{array}{l}\text { Exercise 4: } \\
\text { Social norms }\end{array}$ & $\begin{array}{l}\text { Identify and discuss key social norms and how they impact } \\
\text { on patterns of care work }\end{array}$ \\
\hline & $\begin{array}{l}\text { Exercise 5: } \\
\text { Changes in care }\end{array}$ & $\begin{array}{l}\text { Understand fluctuations and changes in patterns of } \\
\text { providing care, including those due to external events or } \\
\text { policies }\end{array}$ \\
\hline & $\begin{array}{l}\text { Exercise 6: } \\
\text { Problematic care activities }\end{array}$ & $\begin{array}{l}\text { Identify the most problematic care activities for the } \\
\text { community and for women }\end{array}$ \\
\hline \multirow{2}{*}{$\begin{array}{l}\text { Discuss available services } \\
\text { and infrastructure, and } \\
\text { identify options to reduce } \\
\text { and redistribute care work }\end{array}$} & $\begin{array}{l}\text { Exercise 7: } \\
\text { Services available }\end{array}$ & $\begin{array}{l}\text { Identify different categories of infrastructure and services } \\
\text { that support care work }\end{array}$ \\
\hline & $\begin{array}{l}\text { Exercise 8: } \\
\text { Proposed solutions }\end{array}$ & $\begin{array}{l}\text { Identify and rank options to address problems with current } \\
\text { patterns of care work, with a focus on reducing difficulties } \\
\text { and redistributing responsibility for care work, thereby } \\
\text { improving women's lives }\end{array}$ \\
\hline
\end{tabular}

The choice of which RCA exercises to do and which exercises require more attention depends on three factors: the focus of the programme, expected results, and the evidence needed to design further activities and/or advocacy. However, the time-use exercise (Exercise 2) is the most critical exercise in the methodology and should not be excluded. (Time use can be adjusted in humanitarian situations). Below are examples of how decisions were made on the choice of RCA exercises in two scenarios - a post-disaster response, and an enterprise development programme.

\section{Example 1: RCA in a post-disaster response and recovery programme}

After a horrific landslide in an Asian country, work to rebuild the community included a post-disaster response and recovery programme. The immediate needs of the community related to water, sanitation and hygiene, and the provision of health services, since the landslide had destroyed all such facilities. However, leaders needed to know how best to design the programme, which meant they also needed to understand changes in care patterns as a result of the disaster, the prevalence of illness, and the changes in demand for care. They also sought to understand how the disaster had affected the difficulty of conducting some care tasks. The team used RCA methodology to gather this information to inform the programme. Given the evidence they sought to generate, Exercise 2, 3 and 5 , were considered the most important. Exercise 2 enabled participants to estimate the time spent by men and women on unpaid care work, productive work and other activities. Exercise 3 revealed the 
distribution of unpaid care work responsibilities in the household; and Exercise 5 showed how the disaster had affected care tasks such as water collection, care of ill persons, and firewood collection, among others. Participants' responses showed that women were doing most of the care tasks, and that care responsibilities had increased enormously due to the disaster. Participants identified priorities that the programme should consider in the design of postrecovery interventions. As a result, placement of water sources was designed to reduce the distance people needed to travel to fetch water, and the technology used to draw water was such that it could be quickly and easily operated. Community discussions were held to encourage more equitable sharing of care tasks in families. A mobile health unit was put in place to treat illnesses and reduce the time spent caring for sick persons. Childcare facilities were built to increase women's (and men's) mobility and free up their time to participate in other economic activities to help rebuild their community.

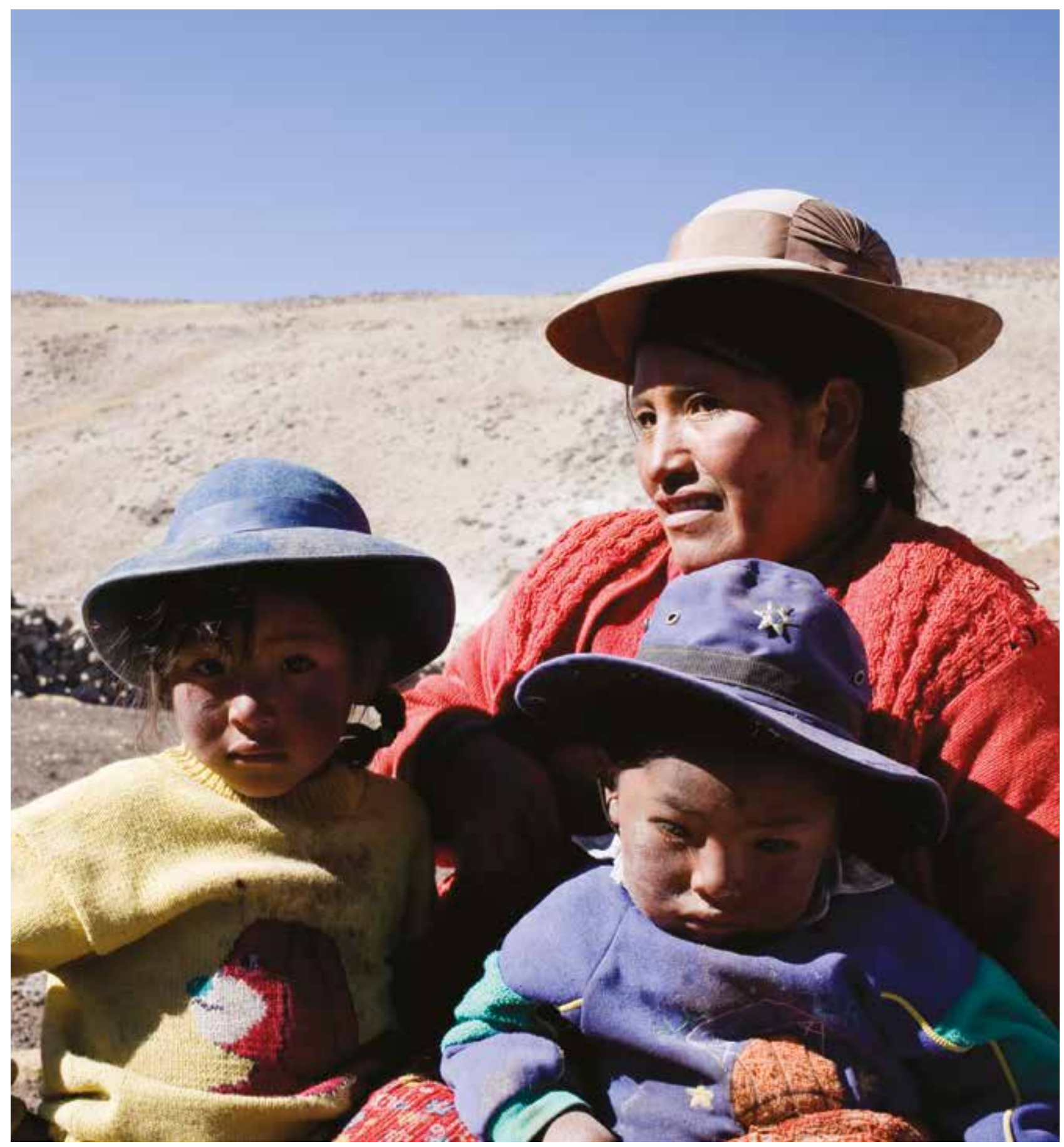




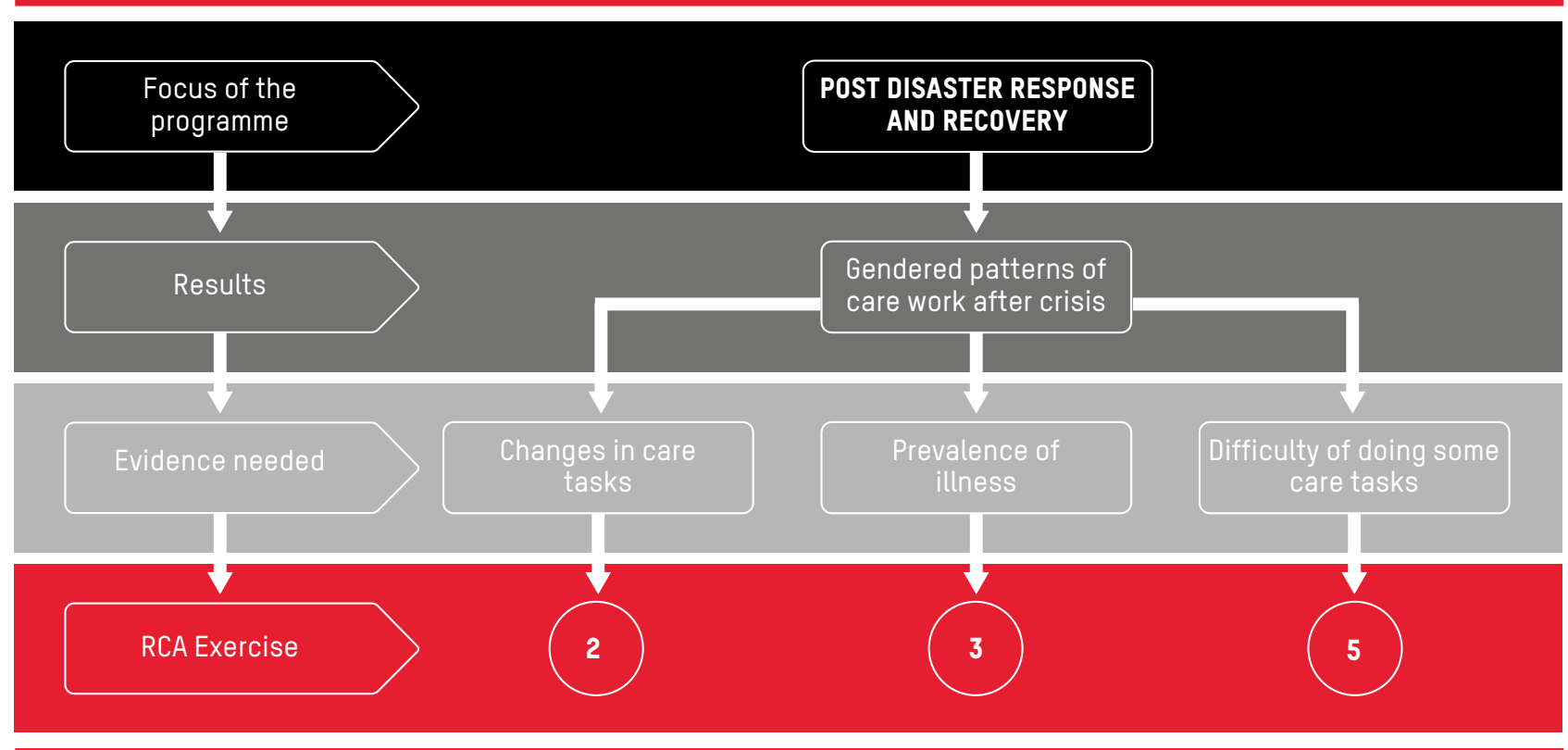

\section{Example 2: RCA in an enterprise development} programme

Similarly, an enterprise development programme in another country had the objective of enhancing women's economic empowerment through participation in agricultural enterprises. To achieve this objective, women needed to have more time to devote to enterprise activities. Thus, in designing the programme, managers were interested in understanding the dynamics of how women currently used their time, and which activities most limited their mobility and hence their potential involvement in processing and marketing activities. They also wanted to understand the social factors influencing the gender roles in paid and unpaid care work. Ignoring these issues in programme design might have been the difference between success and failure of their programme in sustaining women farmers' participation and leadership in the enterprise. Managers therefore decided to use the RCA methodology to explore and understand these issues. Although they conducted all exercises in the methodology, they decided to focus particularly on Exercises 2, 4 and 8. Participants of the RCA clearly recognised the excessive hours women spent on unpaid care activities and the inequality of hours between women and men. They identified childcare and time spent on meal preparation as the priorities for action, as well as the need for awareness-raising to shift norms. Women's heavy workload was due to the cultural norm that care was women's responsibility, and hence women received very little help from other members of the household.
Following the RCA, the programme design included childcare services and efficient meal preparation and preservation technologies. It also included an awareness programme on the importance of unpaid care work and how men could contribute to delivering this social good so that unpaid care tasks could be redistributed more equally.

\subsection{Rapid Care Analysis checklist for planning}

The following checklist will help you to plan for the RCA.

\subsubsection{Planning: four to eight weeks before the RCA}

-Who is facilitating? Decide on the facilitators who will implement the RCA (perhaps staff from your organisation, some partner staff, or a consultant).

- Two facilitators at least: one man and one woman.

- If the facilitator is a consultant, give yourself ample time to allow for the recruiting process.

- Make sure the facilitators have the required skills and competency to run the RCA, and that they are comfortable with the methodology.

- If the RCA will involve children, make sure you include issues of child protection and safeguarding in the contract.

- If facilitators are staff from your organisation or a partner, alert them in time so that they can begin to familiarise themselves with the subject matter and methodology. 


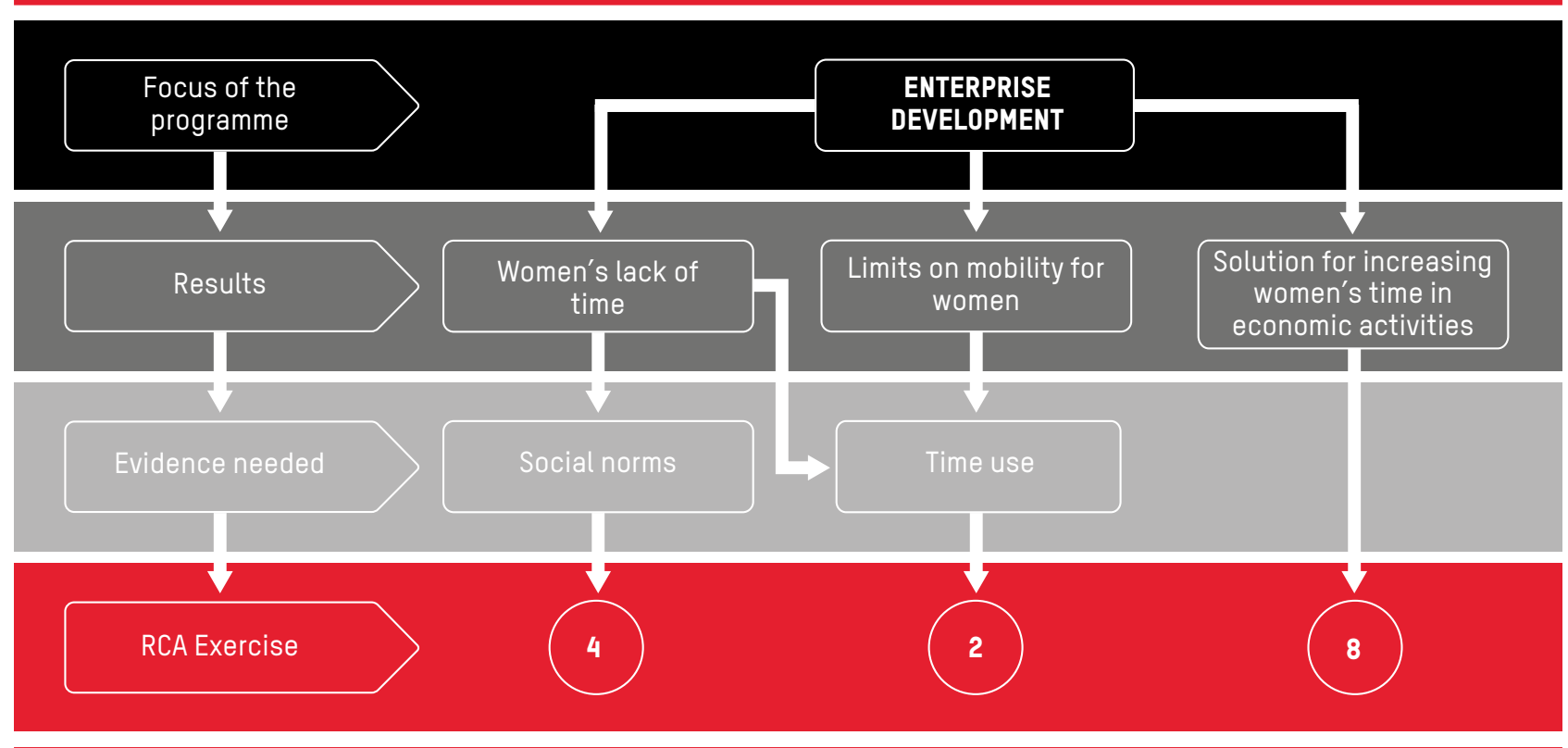

- Who are the other members of the team? Decide who the other members of the team will be, and alert them in good time. Will you require translators? If yes, make sure you have two translators for the RCA.

- When is the 'orientation of facilitation team' workshop? Decide on the date for training facilitators and the wider team on care analysis and the RCA methodology. The date should be within two weeks before the planned date of the RCA.

-When is the briefing of gatekeepers? Identify gatekeepers for the target community. Decide on the approach you will use to sensitise gatekeepers on the need to focus on care and the RCA methodology before you conduct the RCA, e.g. meeting, etc.

- It is good to do this activity after the orientation of the facilitation team.

- Communicate in good time with the leaders, and agree on a date.

\subsubsection{Planning: one to two weeks before the RCA}

- Familiarise yourself with RCA methodology.

- Familiarise yourself with concepts of care and unpaid care work.

- Familiarise yourself with the Toolbox of Exercises:

- It is important that facilitators understand Exercise 2 and are fully comfortable with the methodology, particularly the use of the tables and calculations of hours, and consolidation of hours per activity and weekly totals.
- Decide on how you will conduct the RCA:

- What do you want to achieve?

- How many people are participating? What social groups/categories?

- Which exercises will you use?

- Decide on length la one-day six-hour session, or a two-day 10-hour session).

- How many RCAs do you want to do?

- In deciding who should participate, prioritise the target populations for your programme. Within this group, consider further disaggregation according to age, marital status, vulnerability, etc. For RCAs with children, you might want to consider in-school and out-of-school children, for example.

- Depending on your context and programme, you might consider holding separate group discussions for men and women, or young women and older women, youth and adults, etc.

- Tailor the RCA to the focus of programme. Identify your desired outputs, and consider how the RCA will enable you to achieve them (see section 3.5 on Consider your advocacy strategy).

- Draft 'probing questions' for the different exercises that are relevant for your context and for what you are aiming to learn. Annex 2 from the RCA Toolkit suggests different probing questions for each exercise. 
Please note: The RCA is designed as a one-day or two-day continuous process. However, depending on context, staff time and unplanned circumstances, this might not be possible. In such situations, you might have to stagger the exercises over a longer period of time. It is recommended that staggering only works if you can complete the RCA within a week and with the same people.

\section{- Orientation of facilitation team}

Spend adequate time discussing and working through the methodology with the team that will implement the RCA. This should be at least a full day training and include:

- Understanding and exploring unpaid care - make sure everyone involved in your team understands the concepts (this is likely to involve healthy debate and difficult questions!) and is able to translate them correctly.

- Agree on which words in the local language will be used for different terms. This is important for documentation.

- Use roleplay to simulate each exercise.

- Make sure that everyone is comfortable answering difficult questions, and practises answering them. For example, 'So women do more care work - so what?', or 'Isn't providing money for children's clothes care?', etc.

- If team members are not from the location where you are implementing the RCA, brief them on the context.

- Ensure the documenter has access to the documenting and reporting templates (Toolbox Annex 3 and 4 ) and the 'Guidance for documenters' (section 4.3 below).

\section{- Brief the gatekeepers}

- Plan for a long meeting and prepare well for difficult questions that will come from the leadership.

- It is good to include some of the facilitation team in the meeting.

- Provide refreshments and, if appropriate, compensate transport fares for those travelling from further away.

- You may want to invite one or two leaders to be part of the RCA as observers.

\section{Other logistics of the RCA}

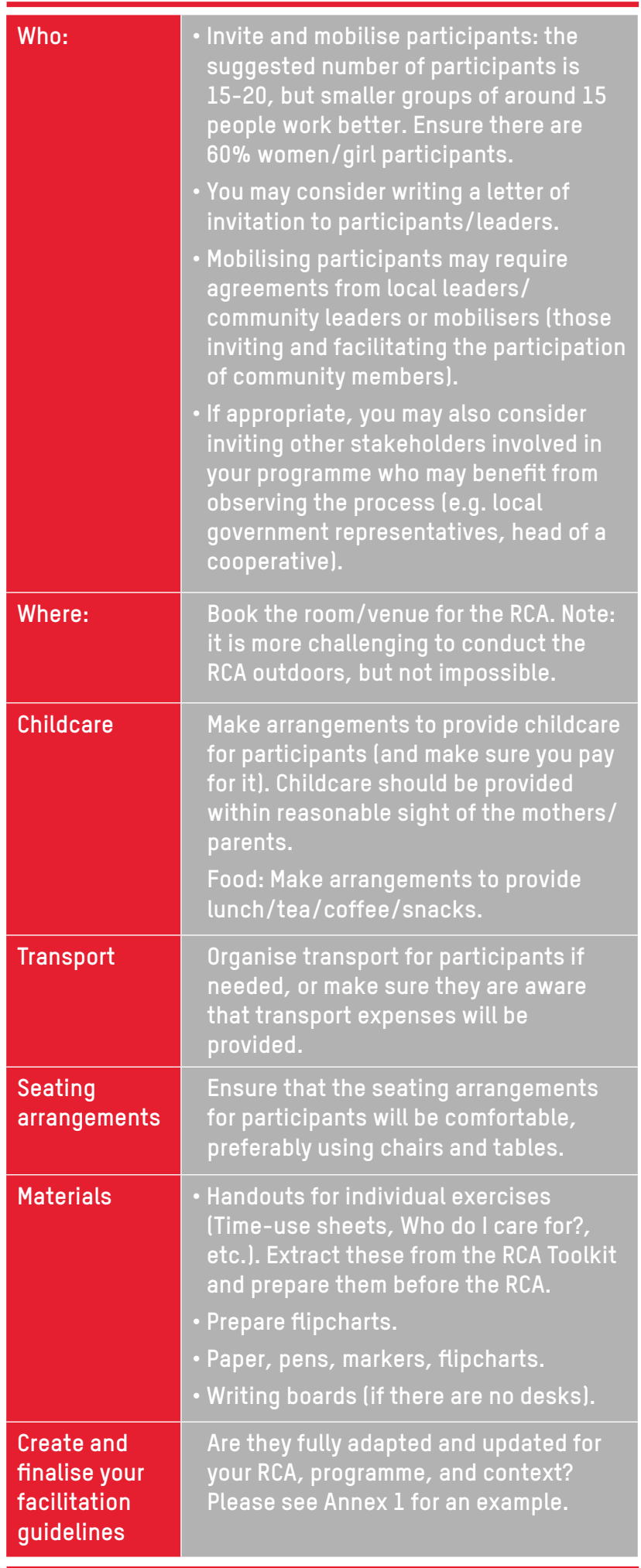




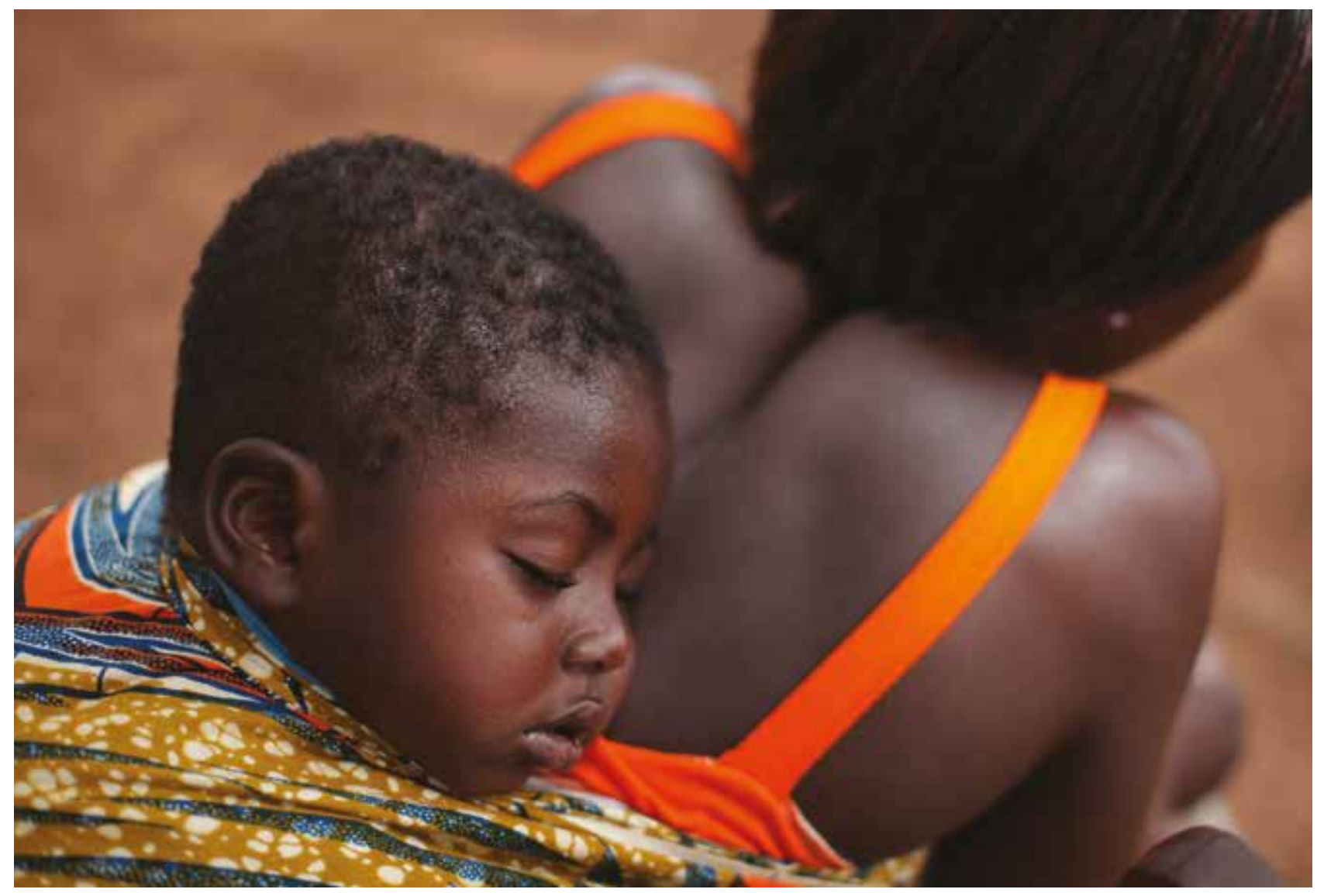

\subsubsection{Final planning - two to three days before the RCA} Who does what?

- As indicated in Section 3.2, you need about four to five people to run an RCA effectively.

- Who is documenting? It has to be one person who has an understanding of care and is fluent in the local language.

-Who is helping illiterate participants? Make sure you have enough people on your team who speak the local language and can support participants with difficulties in reading and writing during the exercises.

-Who is keeping time?

-Who is taking photos?

-Who is translating? (If you need translators.)

-Who is minding the children and babies?

-Who is leading on what? Facilitators should decide who will talk when, who is responsible for explaining which exercises, etc.

\subsubsection{On the day(s) of the RCA}

- Expect to start late and factor that time in.

- Be prepared for, and agree on ways to cope with, unexpected situations:

- More people showing up than expected - can you send them away? Do you have a way of knowing that you have the participants who were invited?
- Fewer people showing up than expected - start when you have $60 \%$ of your numbers? Have someone find more people to join?

- Make the layout of the room comfortable:

- Some leading RCAs have found it works better to have people sitting in a circle discussing the issue, rather than having intricate presentations or slideshows.

- Allow some flexibility to adapt the exercises or spend more time on the ones that need more explanation/ support.

- Adapt discussions to what is said, and ask follow-up questions.

- If participants are illiterate, allow additional time for the exercises where participants provide information on their individual activities and care work. Factor this into the workshop; there may be more illiterate participants than you were expecting, and you are unlikely to know how many until the day itself.

- Observe participants' body language - women and young people may be uncomfortable speaking in mixed groups at the start, but if this remains the case, consider splitting the group for further discussions and then bringing them back together to share. Make sure you create space for women and young people to contribute - this may mean asking women and young people more questions as opposed to asking the whole group. 
- Plan sufficient breaks during the day but try to encourage participants to stay close to the building/ venue (some women may need to breastfeed, go home and prepare lunch, etc.).

- Encourage one male facilitator to sit with the men and one female facilitator to sit with the women.

- Try to stick to the time schedule - have a timekeeper who is communicating with facilitators on sessions lyou may consider having signs with e.g. $10 \mathrm{~min}, 5$ min, 0 min left, that can be held up to facilitators).

\subsubsection{After the RCA}

- Take photos of the flipcharts.

- Debrief with your team: what worked, what could have been done differently, what surprised you, etc. Make sure you document this discussion; it will be crucial for learning and improving.

- Plan a meeting after the RCA with the facilitation team to finalise your advocacy strategy for influencing policy and decision making (see Toolkit Annex 5: Action points for advocacyl.

- Plan a meeting with local government/key stakeholders after the RCA to share initial findings.

- Ensure that the documenter transfers notes to soft/ digital copy if not done during the session.

- Documenter writes the report of the RCA using the reporting template (see Toolbox Annex 4), with input from facilitators and observers to ensure that all the participants' observations and reflections have been captured.

\section{BOX 2: PLEASE NOTE!!!}

In very rare situations where circumstances such as crises, emergencies or conflicts do not allow time for at least a one-day RCA, Oxfam experience has shown that it is possible to get some useful information in 1.5 to 2 hours. The facilitators have to decide on key aspects of the programme and select a few RCA exercises which are critical for it. They can even adapt some exercises so that they collect only the information they require. The exercises can be completed as a group. Alternatively, it is possible to add a session or some questions from the RCA into a rapid needs assessment or gender analysis exercise. Please note that this is not a proper RCA and it is not recommended. However, it is better than nothing.

\subsection{Guidance for documenters - ensuring good quality documentation and reporting}

Ensuring that the RCA is well-documented is critical to the quality of the outcome. As documenter, you should have a clear view of the level of detail required, and the type of information that will be most critical to the analysis.

-Write down participants' exact words when they give opinions about 'why' care work is done as it is, or share local sayings, or stories about good/bad experiences. Ask the person to repeat what she or he said Iduring a break) if you weren't able to write it down.

- If it's essential for your programme to know how care responsibilities affect women's capacity to engage in other activities, such as paid work or political participation, you should keep a detailed record of the hours that women and men allocate to different activities in a day. This can be achieved using the 'individual one-day recall' exercise (Exercise 2) where all daily activities are listed and explored. An in-depth understanding of how women and men manage their time lincluding simultaneous activities and supervision responsibilities) will be essential. Please note that in calculating weekly hours of work, 168 hours a week have to be accounted for.

- If you intend to use the outcomes of the RCA for advocacy work, the numerical evidence that you collect should be supplemented with quotes and detailed stories. This qualitative evidence might show: how people manage their care responsibilities alongside other aspects of their lives; expected or unexpected impacts on care responsibilities of changes in the climate, in the policy environment, or within households; what participants consider their responsibilities to be and why; or what constitutes change for them. When using ranking matrices, it is important to record not only the ranking outcomes (the outcomes should be written into the boxes in the matrix), but also to document the key reasons why the group chose this ranking emerging from the discussions, and any points of disagreements within the group. Disagreements may need to be explored through further probing or individual interviews.

- Use the documentation template (Toolbox Annex 3), and familiarise yourself with the reporting template proposed (Toolbox Annex 4) before the RCA. 


\section{GETTING SUPPORT AND GIVING FEEDBACK}

We hope that this Guidance Document and the accompanying RCA Toolbox will provide you with useful inputs and suggestions for implementing care analysis within your programmes. If you do need additional support or advice in order to start integrating care analysis into your work, please contact Thalia Kidder tkidder@oxfam.org.uk or Jane Remme jremme@oxfam. org.uk, in the first instance.

We would love to hear about your experiences of using RCA in your programmes. What worked well? What didn't work? Did the process generate surprising outcomes? How did you use the outcomes of the process? How could this Guidance Document or the Toolbox be improved? Have you developed or encountered alternative tools that might be useful for others?

We welcome your feedback via the web platform for this project, at http://growsellthrive.org/our-work/ we-care. Your experiences will support further innovation and improvement of tools and approaches for understanding and responding to unpaid care work within Oxfam's programmes.

\section{Sources and bibliography}

ActionAid (2013) 'Making Care Visible: Women's Unpaid Care Work in Nepal, Nigeria, Uganda and Kenya', http:/ / www.actionaid.org/sites/files/actionaid/making_ care_visible.pdf

Budlender, Debbie (ed.) (2010) Time Use Studies and Unpaid Care Work, New York and London: Routledge.

Budlender, Debbie (2004) Why Should We Care About Unpaid Care Work? Harare, Zimbabwe: UNIFEM.

Elson, Diane (2000) Progress of the World's Women 2000, UNIFEM Biennial Report, New York: United Nations Development Fund for Women.

Esquivel, Valeria (2013) 'Care in Households and Communities: Background Paper on Conceptual Issues', Oxford: Oxfam.

Esquivel, Valeria, Debbie Budlender, Nancy Folbre, and Indira Hirway (2008) 'Explorations: time-use surveys in the South', Feminist Economics 14(3): 107-52.

Esquivel, Valeria (2011) 'Sixteen years after Beijing:

What are the new policy agendas for time-use collection?', Feminist Economics 17(4), 215-38.
Eyben, R. (2012) 'The Hegemony Cracked: The Power Guide to Getting Care onto the Development Agenda', IDS Working Paper, Volume 2012 No. 411, Sussex, UK: IDS.

Floro, Maria Sagrario (1995) 'Women's well-being, poverty, and work intensity', Feminist Economics 1(3): 1-25.

Folbre, Nancy (2006) 'Measuring care: gender, empowerment, and the care economy', Journal of Human Development 7(2), 183-99.

Hirway, Indira (2010) ‘Understanding poverty: insights emerging from time use of the poor', in Rania Antonopoulos and Indira Hirway (eds.), Unpaid Work and the Economy: Gender, Time Use and Poverty, New York: Palgrave Macmillan, pp. 22-57.

Kabeer, N. (2008) 'Paid Work, Women's Empowerment and Gender Justice: Critical Pathways of Social Change', Pathways Working Paper 3, Sussex, UK: IDS.

Lucia Rost, Katie Bates, Luca Dellepiane (2015) Women's Economic Empowerment and Care: Evidence for Influencing Baseline Research Report, Oxford: Oxfam, http://policy-practice.oxfam.org.uk/ publications/womens-economic-empowerment-andcare-evidence-for-influencing-578732

Razavi, S. (2007) 'The Political and Social Economy of Care in a Development Context', Geneva, Switzerland: UNRISD, http://www.unrisd.org/80256B3C005BCCF9/ (httpAuxPages)/2DBE6A93350A7783C12573240036 D5A0/ \$file/Razavi-paper.pdf

UNRISD (2010) Combating Poverty and Inequality: Structural Change, Social Policy and Politics, Geneva, Switzerland: UNRISD.

Williams, Fiona (2010) 'Claiming and Framing in the Making of Care Policies: The Recognition and Redistribution of Care', Paper 13, Gender and Development Programme, Geneva, Switzerland: UNRISD. 


\section{ANNEX 1: ADAPTED RCA TOOLKIT FOR RCA WITH YOUNG PEOPLE IN UGANDA}

\section{RCA Guidelines}

\section{Addressing Young People and Care in Uganda \\ Youth Rapid Care Analysis}

\section{Research objectives}

1. To explore how and why care work is distributed between genders and age groups.

2. To understand the consequences for young people of heavy and unequal unpaid care work.

3. To explore the perceptions and attitudes of young women and men towards care work and the associated gender norms.

4. To support young people to develop strategies (including awareness-raising and advocacy initiatives) to recognise, reduce and redistribute heavy and unequal care among youth and communities, and to represent their voices in decision-making processes.

5. To develop recommendations for Oxfam's future youth programming on the integration of unpaid care issues.

\section{Research tool}

A Youth Rapid Care Analysis (RCA) will be used for the research project into youth and unpaid care. The Youth RCA is a one-day workshop with a set of exercises with children and youth community members that provides them with a space to explore the area of care together, to look at what factors shape youth norms and perceptions about gender roles, age and care work, and to collaboratively develop practical solutions and strategies to address the issues identified. The RCA aims to recognise care work and patterns of care, to identify the social norms underlying these patterns, to acknowledge the 'most problematic' care activities, and to develop proposals to recognise, reduce and redistribute care work and represent young carers in decision-making. The exercises use several visual tools, such as matrices and maps, as well as open discussions. The RCA is intended to be quick to use and easy to integrate into existing exercises for programme design or monitoring. It can help assess how young women's and girls' involvement in care work may impact on their lives and participation in development projects.

\section{Specification}

- 4 RCAs will be carried out in Mpigi District in Uganda.

- Each RCA should have 16-18 participants.

- Participants should be made up of 1-2 more girls compared to boys. The facilitator will ensure that girls are not dominated by boys.

- The RCA team should ideally be comprised of 2 consultant facilitators, 1-2 support staff, and 1-2 rapporteurs. 
Different groups for RCAs:

1) 9 -12 age group

2) 13-17 age group - in-school

3) 13-17 age group - out-of-school, including some who are married, breastfeeding, have children, do/don't live with parents etc.

4) 18-25 age group

\section{Outline}

1) Introduction

2) Who do we care for?

3) Who does what?

4) How is care split between gender and age?

5) What makes a 'good' woman/man?

6) Most problematic care activities

7) Developing options and solutions

8) Conclusion

\section{Detailed agenda}

1) INTRODUCTION

1. Welcome

2. Introductions

\section{Discuss what is unpaid care work}

a. Ask people what they think is unpaid care work

b. Show photos of girls and women doing work and ask what is happening in each of the pictures and what people think is care work

c. The definition that the WE-Care project uses is: Unpaid care work is domestic work and direct care of persons which facilitates and supports the well-being of family and community members. It is often little recognised and performed by women.

d. Show the diagram with the care categories and explain it

\begin{tabular}{l|l}
\hline Domestic work & Direct care of persons \\
\hline Meal preparation & Childcare \\
Water & Care of dependent adults \\
Energy & Care of community members \\
Clean space & Care for the sick \\
Clean clothes & \\
\hline
\end{tabular}

e. Ask whether people agree or want to add more categories

2. Answer questions about what is care work and what is not

\section{2) WHO DO WE CARE FOR?}

1. Clarify objective: to find out who boys and girls care for in their family and community

2. Two flipcharts with care circles, one for girls, one for boys

a. Explain that we want to brainstorm who girls and boys care for on a daily, weekly, monthly basis

b. Split the group into girls and boys (or to save time do together with girls and boys)

c. Ask people 'who do you care for?'Write down the RELATIONSHIPS to the person le.g. grandfather, mother, younger brother) in the circle for women or men 
d. Some probing questions:

i. Who do you cook for? Wash clothes for? Clean for?

ii. Do you watch over your own siblings (children)?

iii. Do you watch over any other children in addition to your own siblings?

iv. Do you ever help ill people in other households?

v. To whom do you give moral support?

e. Make sure that participants think about all the care categories

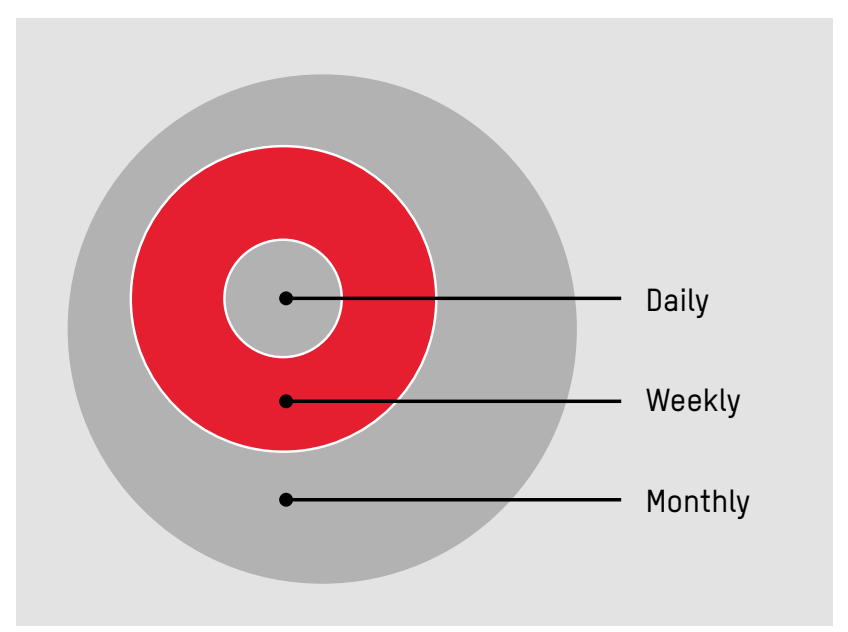

f. Discuss the findings, differences and related norms, for example ask: What type of people care more, what people care less? Why?

\section{3) WHO DOES WHAT?}

1. Clarify objective: to find out who does what type of work, THIS IS NOT ONLY ABOUT CARE WORK

2. Split the group into girls and boys

\section{Explain one-day recall exercise}

a. Write down what you did yesterday in each hour of the day

b. Also note SIMULTANOUS ACTIVITIES: this is something you do at the same time as something else le.g. looking after a child while cooking). Explain examples to make sure participants understand what you mean. Make sure for each hour you ask whether they were also responsible for looking after a child or ill/elderly/disabled adult during that hour. Ask whether yesterday was an ordinary day and if not ask what was unusual

4. Distribute one-day recall table. For in-school children, this exercise can be quick if much of the day was spent in school

5. Are there particular day(s) in a week when care activities are more than on other days? (Probe for particular days and activities undertaken on those days) 


\begin{tabular}{|c|c|c|c|c|c|c|}
\hline Time & Main activity & Symbol & $\begin{array}{l}\text { Simultaneous } \\
\text { activity }\end{array}$ & Symbol & $\begin{array}{l}\text { Responsible for } \\
\text { looking after child or } \\
\text { dependent adult? }\end{array}$ & Symbol \\
\hline \multicolumn{7}{|l|}{$12.00-01.00$} \\
\hline \multicolumn{7}{|l|}{$01.00-02.00$} \\
\hline \multicolumn{7}{|l|}{$02.00-03.00$} \\
\hline \multicolumn{7}{|l|}{$03.00-04.00$} \\
\hline \multicolumn{7}{|l|}{$04.00-05.00$} \\
\hline \multicolumn{7}{|l|}{$05.00-06.00$} \\
\hline \multicolumn{7}{|l|}{$06.00-07.00$} \\
\hline \multicolumn{7}{|l|}{$07.00-08.00$} \\
\hline \multicolumn{7}{|l|}{$08.00-09.00$} \\
\hline \multicolumn{7}{|l|}{$09.00-10.00$} \\
\hline \multicolumn{7}{|l|}{$10.00-11.00$} \\
\hline \multicolumn{7}{|l|}{$11.00-12.00$} \\
\hline \multicolumn{7}{|l|}{$12.00-01.00$} \\
\hline \multicolumn{7}{|l|}{$01.00-02.00$} \\
\hline \multicolumn{7}{|l|}{$02.00-03.00$} \\
\hline \multicolumn{7}{|l|}{$03.00-04.00$} \\
\hline \multicolumn{7}{|l|}{\begin{tabular}{|l}
$04.00-05.00$ \\
\end{tabular}} \\
\hline \multicolumn{7}{|l|}{$05.00-06.00$} \\
\hline \multicolumn{7}{|l|}{$06.00-07.00$} \\
\hline \multicolumn{7}{|l|}{$07.00-08.00$} \\
\hline \multicolumn{7}{|l|}{$08.00-09.00$} \\
\hline \multicolumn{7}{|l|}{$09.00-10.00$} \\
\hline \multicolumn{7}{|l|}{$10.00-11.00$} \\
\hline $11.00-12.00$ & & & & & & \\
\hline
\end{tabular}

\section{Help the illiterate}

7. Make sure that people note simultaneous activities by asking probing questions on less visible types of care work

8. Some probing questions:

a. What did you do at the same time?

b. While you were asleep were you responsible for looking after children?

c. Did you look after/were you responsible for looking after children or adults at this time?

9. If the concept of hours is too difficult, use visual cards and beans to allocate hours

10. After about 15 minutes, present symbols of care work. Check beforehand that these symbols are recognisable for children

\begin{tabular}{|l|l|}
\hline Category of work & Symbol \\
\hline Paid labour, paid services & \\
\hline Work to produce products for sale & \\
\hline Unpaid work producing products for home consumption & \\
\hline Unpaid care work & \\
\hline Unpaid community work & \\
\hline Non-work & \\
\hline
\end{tabular}


11. Ask participants to add the matching symbols behind the activities on their one-day recall

12. Help the illiterate

13. Individual summing up table

a. Ask participants to count the hours they spent on each category of work by counting the symbols and to note it in the table

b. Make sure that they count both main and simultaneous activities

14. Collective summing up table

a. Ask participants to read out the numbers of hours spent on each type of work for both simultaneous and main activities

b. Note the numbers of all participants in the collective summing up table

c. Calculate the average number of hours spent on each type of activity per week

d. Discuss with the group whether this number is representative for the hours girls/boys spend on this type of activity per week

e. Adjust the number in case it is not representative

\begin{tabular}{|l|l|l|l|l|}
\hline Activity & $\begin{array}{l}\text { Daily hours as main } \\
\text { activity }\end{array}$ & Weekly average & $\begin{array}{l}\text { Daily hours as } \\
\text { simultaneous activity }\end{array}$ & Weekly average \\
\hline & & & & \\
\hline & & & & \\
\hline & & & & \\
\hline & & & & \\
\hline Total & & & & \\
\hline
\end{tabular}

15. Bring groups together

16. Present average hours spent on each activity per week of girls and boys and total hours of work

17. Discuss differences and ask why

18. Some probing questions:
a. What striking differences stand out between what girls do and what boys do?
b. Were you aware of these differences?
c. Why do you think there are differences?
d. Are girls doing more simultaneous activities than boys? Which ones? Why?
e. Can you think of cases or families where work is distributed differently?

19. Ask what participants would do if they had more time. Use cards for children to choose what activities they would be doing with more time - e.g. sleeping, playing, studying

\section{4 a) AGE, GENDER AND CARE}

1. Clarify objective: to find out who does what care work, especially with regard to age and gender

\section{Explain age distribution matrix}

a. Explain that the table looks at how much time women, men, girls, boys, female and male teenagers, older women and older men spend on care work

b. Explain the meaning of the dots:

i. 3 dots: more than 10 hours per week

ii. 2 dots: 5 - 10 hours per week

iii. 1 dot: less than 5 hours per week

iv. No dots: never

c. Fill in the table collectively

d. Make sure that the discussion includes everyone 


\begin{tabular}{|c|c|c|c|c|c|c|c|c|}
\hline & Girl & Boy & $\begin{array}{l}\text { Teenage } \\
\text { girl }\end{array}$ & $\begin{array}{l}\text { Teenage } \\
\text { boy }\end{array}$ & $\begin{array}{l}\text { Middle-aged } \\
\text { woman }\end{array}$ & $\begin{array}{l}\text { Middle- } \\
\text { aged man }\end{array}$ & $\begin{array}{l}\text { Elderly } \\
\text { woman }\end{array}$ & $\begin{array}{l}\text { Elderly } \\
\text { man }\end{array}$ \\
\hline Fetching water & & & & & & & & \\
\hline Cooking & & & & & & & & \\
\hline Collecting firewood & & & & & & & & \\
\hline $\begin{array}{l}\text { Cleaning house/ } \\
\text { compound }\end{array}$ & & & & & & & & \\
\hline Washing clothes & & & & & & & & \\
\hline Ironing clothes & & & & & & & & \\
\hline Washing utensils & & & & & & & & \\
\hline Care for children & & & & & & & & \\
\hline $\begin{array}{l}\text { Care for dependent } \\
\text { adults (elderly, sick) }\end{array}$ & & & & & & & & \\
\hline $\begin{array}{l}\text { Food production for } \\
\text { family }\end{array}$ & & & & & & & & \\
\hline
\end{tabular}

3. Ask why some people do more and some people do less care work. Some probing questions as a way to talking about norms:

i. Do girls or boys care more? Why?

ii. Do old or young people care more? Why?

iii. Are there certain tasks which girls and women do more? Why?

iv. Do boys or teenagers care more than men? Why?

v. Do older or younger girls care more?

\section{4 b) SEASONAL CHANGES IN CARE}

1. Clarify objective: to understand when in the year care activities are most problematic

\section{Seasonal calendar}

a. Start with one category of care work and ask 'when is this most difficult/most intense' and why?

b. Put a cross for the months the activity is most problematic in

c. Ask when any agricultural or other work is most problematic (e.g. helping with harvesting)

d. Draw conclusions from the matrix about most difficult months for care work

\begin{tabular}{|c|c|c|c|c|c|c|c|c|c|c|c|c|}
\hline Symbols & Jan & Feb & Mar & Apr & May & Jun & Jul & Aug & Sep & Oct & Nov & Dec \\
\hline & & & & & & & & & & & & \\
\hline & & & & & & & & & & & & \\
\hline & & & & & & & & & & & & \\
\hline & & & & & & & & & & & & \\
\hline & & & & & & & & & & & & \\
\hline & & & & & & & & & & & & \\
\hline & & & & & & & & & & & & \\
\hline & & & & & & & & & & & & \\
\hline & & & & & & & & & & & & \\
\hline
\end{tabular}




\section{4 c) CHANGES IN CARE}

1. Clarify objective: to find out whether anything else affects patterns of care work

2. Ask participants if there are any other factors determining the amount of care work they do

3. Some probing questions:

a. Has care work become more or less over the last years? Why?

b. How do the following factors affect care work?

i. Climate change: drought, flood, deforestation

ii. Land-related issues

iii. Work in the mines/urbanisation

iv. Illnesses, such as TB, malaria and HIV

v. Having an extended or nuclear family

vi. Availability of basic services

4. This exercise should be adapted dependent on the age of the participants and time available

\section{5) HOW IS CARE WORK PERCEIVED? WHAT SHOULD MEN AND WOMEN DO?}

1. Clarify objectives: al perceptions of care work: to find out how participants and their peers perceive care work, and b) gender roles and care work: to find out what participants and their peers think women and men should do in terms of tasks and roles in paid and unpaid work (how gender roles and care roles interact).

2. Split the group into men, boys, women, and girls (or to save time combine women/girls and men/boys).

3. Give each group two flipchart papers - one with Table 8 on it (perceptions of care work) and the other with Table 9 on it (what should women and men do).

4. Ask participants to share how they and their peers perceive care work in general, and then specifically some of the key care tasks done in their community. Ask them to fill in the table (Table 8), listing whether activities are enjoyable/desirable, important/valuable and require skill (YES or NO answers) for women and for men.

5. Ask participants to say what they think a 'good' woman should do, and what a 'good' man should do, listing tasks for women and men in Table 9 based on this. The men should start with the question, 'What should women do?' whilst the women start with the question, 'What should men do?'. This can be built on by asking what makes a 'good' wife/husband, mother/father.

6. Some probing questions:

i.How do you perceive care work? How skilled, important, difficult, and desirable/enjoyable is this work?

ii.How does care work compare to paid work? Is it equally, more, or less valuable?

iii.What tasks should women/ men do? Why?

iv. What tasks are acceptable for women/men to do? Why?

v.How do you know that women/men should do these tasks? Who says so?

vi.What would a group of your peers consider to be acceptable for women/men to do? Why?

vii.Who makes the largest contribution? Why?

viii. Who does the most important work? Why?

ix. Who does the hardest work? Why?

\section{6) MOST PROBLEMATIC CARE ACTIVITIES}

1. Clarify objective: to find out what care activities are most problematic to help us develop solutions to address these issues

2. Ask whether people think care work is problematic and should be reduced

3. Split participants in two groups: 1) girls and 2) boys (or to save time do the ranking matrix together with girls and boys)

4. Remind people of the care categories and ask them to think about the activities they noted in their one-day recall

5. Ask participants to think about what care activity is most problematic

6. Decide on the 3-5 most problematic care activities 


\section{Ranking matrix}

a. Fill in the most problematic care activities in the matrix

b. For each problematic care activity assign dots to assess:

i. how much it is a time burden

ii. how much it affects mobility

iii. how much it affects health

iv. how much it affects ability to do other activities: education; social activities; paid work; agriculture; individual/collective action; leisure; participation in programmes/training, etc. lchoose 1-2 to add to the table)

v. how much it causes harmful behaviour: criticism; humiliation; violence; risk (choose 1-2 to add to the table)

c. Explain the meaning of the dots:
i. 3 dots: most challenging
ii. 2 dots: manageable
iii. 1 dot: simple

\begin{tabular}{|l|l|l|l|l|l|}
\hline & Time burden & Mobility & Health & $\begin{array}{l}\text { Other effects, e.g. } \\
\text { education }\end{array}$ & $\begin{array}{l}\text { Other effects, e.g. } \\
\text { criticism }\end{array}$ \\
\hline Activity 1 & & & & & \\
\hline Activity 2 & & & & & \\
\hline Activity 3 & & & & & \\
\hline Activity 4 & & & & & \\
\hline
\end{tabular}

\section{Bring groups together}

9. Ask each group to present and explain their ranking

\section{7) DEVELOPING OPTIONS AND SOLUTIONS}

1. Clarify objective: to come up with solutions for most problematic care activities that are feasible and impactful

2. Present 'care diamond' and 'four Rs'

3. Brainstorm options to recognise, reduce, redistribute and represent care work:

a. Focus especially on the most problematic activities

b. If one activity is by far the most problematic activity you might want to only focus on this

c. Make sure that people think about strategies at household, community, civil society, market and state levels

d. Make sure that the discussion includes everyone

e. Some probing questions:

i. What forms of social innovations (labour-sharing, support for childcare) and technological innovations (pounding mills, washing machines) could be developed or strengthened in order to reduce the time or labour that care work requires of individual women?

ii. What additional resources, institutions, services, or subsidies can be used to reduce the difficulties and costs of care work done at household level?

iii. Which officials and institutions Igovernments, companies, trade associations, NGOs, religious organisations) could be called on to make decisions to support or invest resources to reduce/redistribute care work?

iv. How can the voices of girls and boys as well as women and men who provide care, be better represented in decision-making? 
v. How can care work be redistributed within the household, between girls and boys, women and men or between different generations?

A) Encourage participants to think about the role of influential people, e.g. teachers, parents and religious leaders in changing norms and encouraging redistribution of care work. (Note: these answers could be based on the people identified in Exercise 5, answers to the question: 'How do you know that women and men should do these things? Who says so?')

B) Based on the discussion questions at the end of Exercise 3 and in Exercise 5, ask: Why do you think that boys/men do not normally do these care tasks? What might encourage them to take on these tasks?

\section{Solution ranking matrix}

a. Enter the best four options in the matrix. This should include at least one option for reducing care work and one option for redistributing care work

b. Look at each option and see whether it is feasible and impactful, following the sub-categories

c. Explain meaning of dots:

i. 3 dots: strongly agree

ii. 2 dots: agree

iii. 1 dot: disagree

iv. no dots: strongly disagree

d. Fill in the matrix collectively

\begin{tabular}{|l|l|l|l|l|}
\hline & Option 1 & Option 2 & Option 3 & Option 4 \\
\hline Saves time & & & & \\
\hline Improves quality of life & & & & \\
\hline Financially feasible & & & & \\
\hline Achievable & & & & \\
\hline
\end{tabular}

5. Ask people to explain why they like the solution or not

6. Draw conclusions about the best solutions

7. Discuss potential unintended negative consequences of solutions, e.g. decreased quality of care work, gender-based violence, and stigmatisation.

\section{8) CONCLUSION}

1. Explain again what will happen after the RCA

2. Thank everyone 


\section{Notes}

1. See Cascant Sempere, M. (2015). Redistributing Care Work for Gender Equality and Justice: A Training Curriculum. Published by ActionAid, Institute for Development Studies, and Oxfam GB. Retrievable from: http://policy-practice.oxfam.org.uk/publications/ redistributing-care-work-for-gender-equality-andjustice-a-training-curriculum-583239

2. For a training webinar on the Rapid Care Analysis, please see: http://growsellthrive.org/our-work/ we-care

3. Most of these concepts are explained in more detail in Esquivel V. (2013) 'Care in Households and Communities, Background Paper on Conceptual Issues'. Available at: http://policy-practice.oxfam.org. uk/publications/care-in-households-andcommunities-background-paper-on-conceptualissues-302287

4. Diane Elson (2000) initiated the concept of the Triple ' $R$ ' (recognition, reduction, and redistribution) in dealing with unpaid care work, while the fourth ' $R$ ', i.e. representation, came from the work of Oxfam, ActionAid and IDS.
5. Valeria Esquivel (2013): Actors adopting a social justice perspective may consider care to be a 'right', while those adopting a social investment perspective may view care as a poverty or a lack of employment issue (Williams 2010). Diagnoses that emphasise gender, class, and race inequalities in care provision highlight women's costs of providing care. They call for the redistribution of care responsibilities, in particular through active state interventions with universal scope (UNRISD 2010). Diagnoses that focus on the role of care in the production of 'human capital', or the efficiency gains of women's partaking in the labour market when care services are publicly provided or subsidised, usually justify interventions that are focused on 'vulnerable' or dependent population groups. Such focused interventions may sideline women's (and others') equality claims.

6. Please note: it is not necessary to hire 'gender experts' to be facilitators but they should possess a working knowledge on gender, and have experience discussing gender equality issues in mixed groups.

7. https://sumus.oxfam.org/oxfam-strategicplan-2013-19/wiki/enabling-change-goal-groupworldwide-influencing-network-win. Please note the guidelines are not open access but are only available to Oxfam staff.

8. For more information on power analysis, please visit: http://www.slideshare.net/RichardEnglish/calp-5webinar-on-power-final?next_slideshow $=1$ 


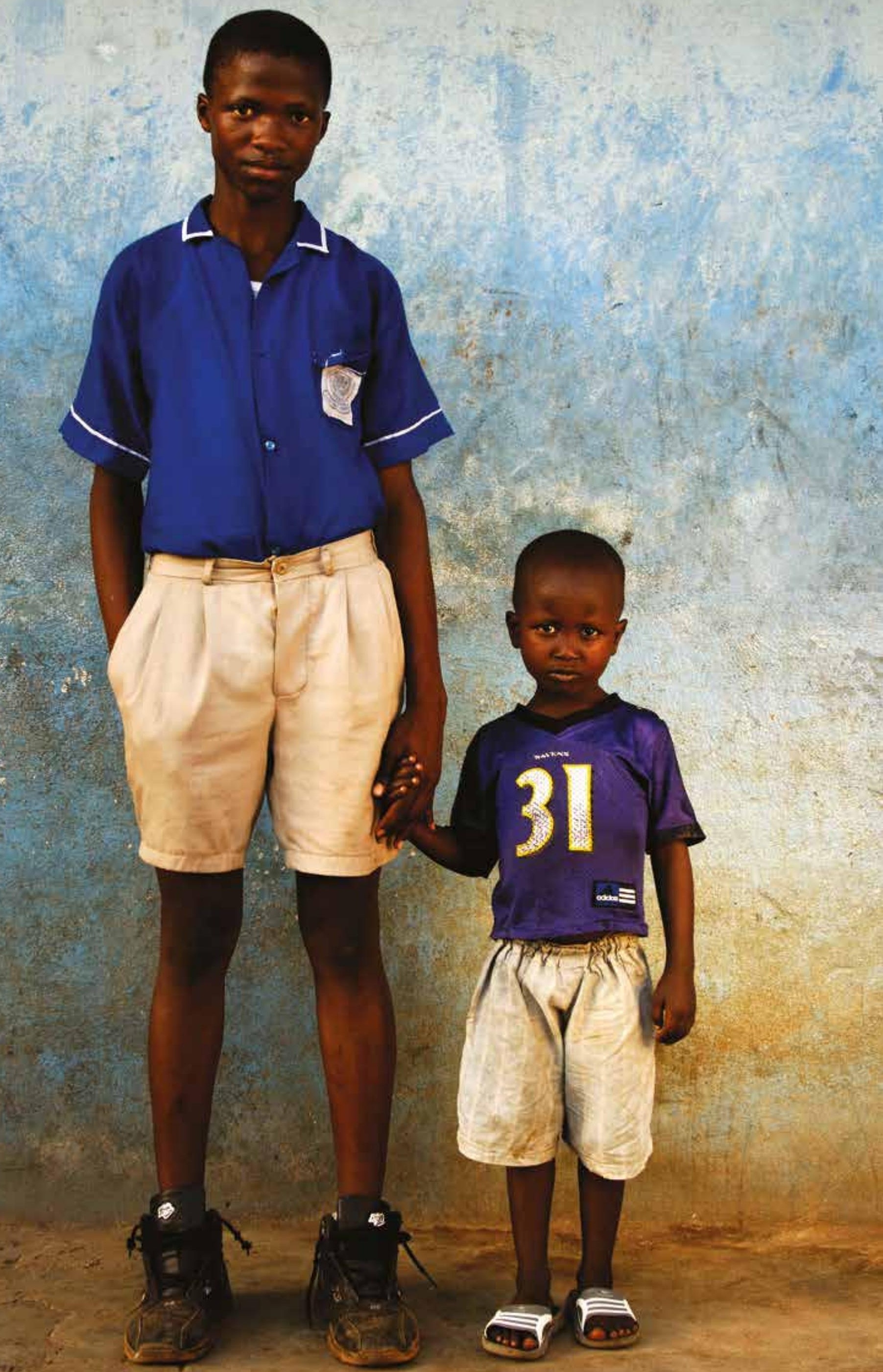



Women's Economic Empowerment and Care (WE-Care) is Oxfam's initiative in 10 countries that supports women's empowerment by addressing excessive and unequal care work - building evidence, promoting positive norms, new investments and policy advocacy.

www.oxfam.org.uk/care

wecare@oxfam.org.uk

With thanks to our partner, the William and Flora Hewlett Foundation, for supporting the WE-Care programme.

Hewlett

Foundation

Photos:

Page 1: Abbie Trayler-Smith

Page 3: Gilvan Barreto

Page 8: Kieran Doherty

Page 13: Gilvan Barreto

Page 17: Abbie Trayler-Smith

Page 30: Aubrey Wade

\section{WE-CARE \\ WOMEN'S \\ ECONOMIC \\ EMPOWERMENT \\ AND CARE}

